\title{
Analysis of modular transport systems functioning in selected European countries
}

\author{
Anna Dzioba $^{1,}{ }^{*}$, Marietta $M$ arkiewicz ${ }^{2}$ and Jan Gutsche $^{2}$ \\ ${ }^{1}$ Cuiavian University in Wloclawek, Faculty of Social and Technical Sciences, Okrzei 94A, 87-800 \\ Włocławek, Poland \\ 2UTP University of Science and Technology, Faculty of Mechanical Engineering, Al. prof. S. \\ Kaliskiego 7, 85-796 Bydgoszcz, Poland
}

\begin{abstract}
This study presents an analysis of transport modular systems in selected European countries. The European Modular System is characterized and legal acts concerning transport means and systems used for this form of transport are discussed. The study focuses on the E uropean countries which take advantage of this system and the scope of its utilization. Based on the literature and source materials, a comparative analysis was performed and purposefulness the European M odular Systems in Europe was determined.
\end{abstract}

\section{Introduction}

European Modular Systems (EMS) started functioning in the $30^{\text {th }}$ of the $X X$ century. A ustralia was the first country to use EM S. These vehicles were used for intercity transport over longer distances [1]. A common name of EM S is a road train. These systems found also application in such countries as: Canada, the U nited States, M exico and A rgentina [2].

In Europe the first country to implement such systems was Sweden where heavier and longer systems were gradually implemented. It was a time of dynamic development of road infrastructure and the net of warehouses. Logistic centers and terminals came into being which resulted in an increased demand for transport of oversize loads with the use of EMS [1].

The next country which introduced modular systems was Netherlands. Introduction of modular systems caused extension of the vehicle length up to $25.25 \mathrm{~m}$ and the mass up to 50 tons. Also Denmark, Finland, Belgium, Germany Norway and other European countries belong to the group of countries that have been gradually introducing this kind of transport. [1,2].

\section{Characteristics of the European Modular Systems}

European Modular System is used consistently with Directive of the European Council 96/53/W E of 25 J uly 1996. This directive is the major legal act regulating maximal permitted parameters of vehicles moving on the roads of the European Union. The most significant normative units included in the Directive specify [2]: maximal allowable vehicle length (engine vehicle or semitrailer - $12 \mathrm{~m}$, articulated truck - $16.50 \mathrm{~m}$, truck train- $18.75 \mathrm{~m}$ ), maximal vehicle width (all vehicles - $2.55 \mathrm{~m}$, upper deck of a freezer truck - $2.6 \mathrm{~m}$ ), maximal allowable height $-4,00 \mathrm{~m}$, maximum authorized weight (road trains or articulated trucks -40.0 tons, articulated vehicles carrying 40 -feet containers -44.0 tons).

According to the "modular concept" specified in art. 4 of 96/53/WE Directive, each country can enter into service vehicles whose length and maximum authorized weight are bigger than normative. According to this concept, a nonnormative vehicle or a system of vehicles can be replaced by a nonnormative road train [2]. M ore and more countries choose

* Corresponding author: annadziobal@ gmail.com 
to introduce the M odular Transport System. This is caused by an increase in the demand for road transport. More and more goods are carried by road transport. Therefore, new investments connected with modernization and construction of infrastructure are being implemented. This, however, does not meet the growing transport demand [3]. A s the study shows, introduction of the EMS is associated with transport cost reduction, $\mathrm{CO} 2$ emission reduction [4-8] and decreasing the number of vehicles on the road [3,9].

Use of this type of vehicles contributes to a transport capacity increase while reducing the company own costs [2].

However, it should be borne in mind that when analyzing this issue, it should be considered both in terms of efficiency and safety, reliability and environmental friendliness of operation [10-13].

For the last years the European countries have been extending allowable load capacities of vehicles from 10 to 30 tons, which is presented in figure co 1 [14].

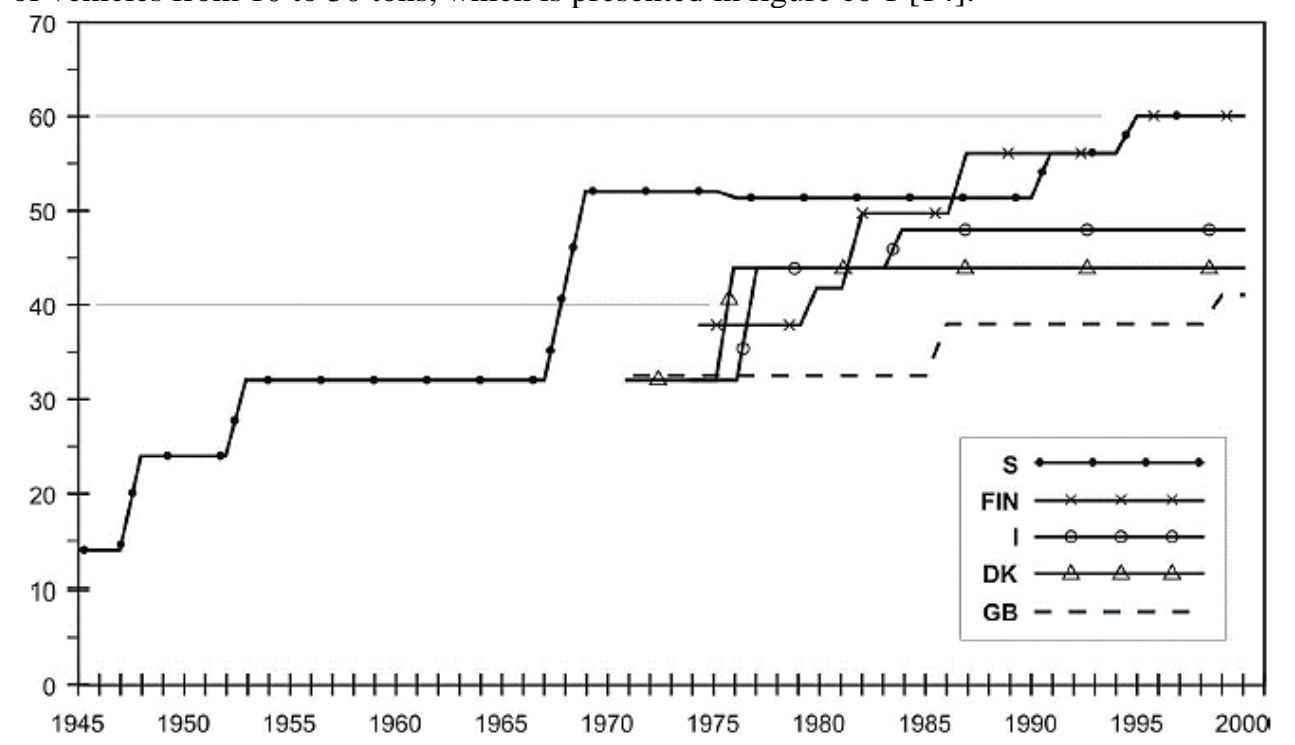

Fig. 1. Change in the allowable maximal weight of vehicles inn selected European countries from 1945 (in tons) [14].

The EM S (European M odular System) uses transport vehicles currently used in Europe. The EM S comes under names such as: road trains, EuroC ombi, M egaliner, Gigaliner, (L HV) Longer and Heavier V ehicles, M egatruck [2, 18].

The EM S systems consist of standard and nonstandard modules such as: truck tractor, articulated truck, $13.7 \mathrm{~m}$ long articulated trailer, $7.82 \mathrm{~m}$ long trailer, 2-axial truck, $7.82 \mathrm{~m}$ special 3-axial articulated trailer with removable container/body at the front, equipped with a fifth wheel for attachment of another articulated trailer. Utilization of these modular vehicles (standard and nonstandard) all ows for combination of five possible systems of truck trains $[18,19]$. 


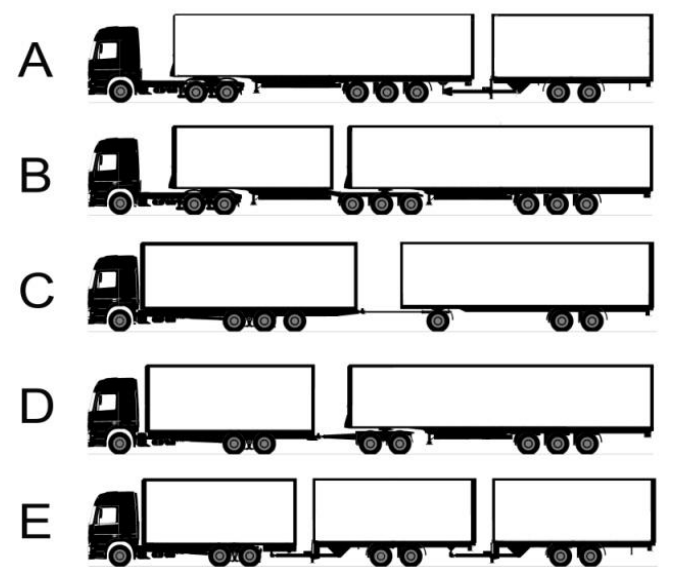

Fig.2. Possible combinations of modular systems [18].

The combinations of modular transport systems presented in figure 2 represent [18]:

- combination A - 2/3-axial truck tractor hooked with a 3-axial articulated trailer $13.6 \mathrm{~m}$, hooked with 8 central trailer with the length up to $7.82 \mathrm{~m}$,

- combination B - 2/3-axial road tractor connected with a special articulated trailer to be hooked on a standard articulated trailer $13.6 \mathrm{~m}$ long,

- combination C - 4-axial 8x2/8x4 chassis hooked with a 3-axial trailer,

- combination D - 3-axial chassis $6 \times 2 / 6 \times 4$ hooked by a fork lift truck and 3-axial articulated trailer $13.6 \mathrm{~m}$,

- combination $\mathrm{E}$ - two-axial chassis hooked with two tandem trailers with $7.82 \mathrm{~m}$. long central axle.

A s the analyzed data shows, combinations of modular systems used in European countries are $25.25 \mathrm{~m}$ long and it is possible to arrange and disarrange them differently to provide both normative and nonnormative vehicles. Such a solution allows to transport the same amount of load by two systems of modular vehicles, thus replacing three standard vehicle systems which are presented in figure $3[1,16]$.
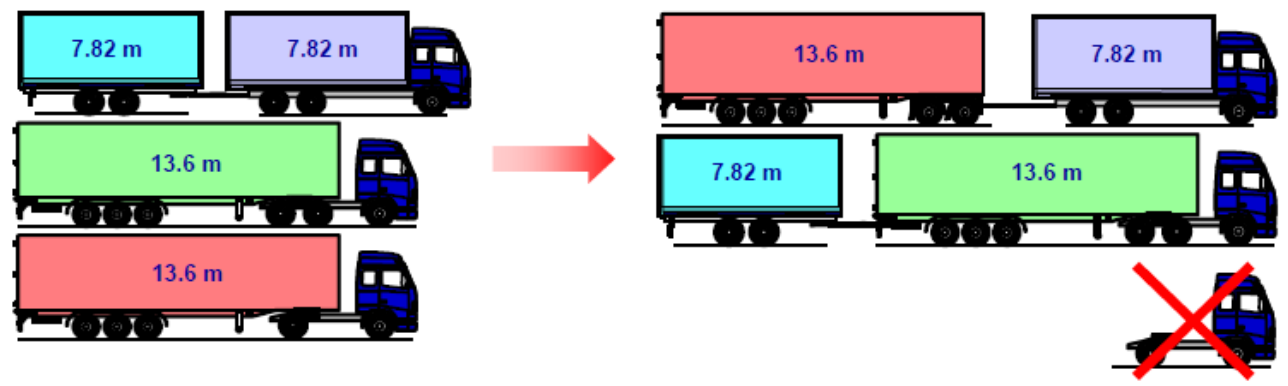

Fig. 3. Comparison of a standard system with the EM S concept $[1,9]$.

\section{Modular Transport System in European countries}

European M odular Systems have become an alternative for nonnormative high capacity vehicles. $M$ any E uropean countries use this type of systems whose functioning is regulated by domestic legal acts. The study focuses on the countries which for the last 20 years have been introducing regulations on the use of the EMS. There is a number of countries which accept deviations from dimensions and load capacity as set out in the Directive, though Scandinavian countries are still leaders in this field [17]. 


\subsection{Sweden}

Sweden is one of the first countries to use vehicles longer than the normative ones. Initially, in 1968 there were no restrictions concerning the vehicle length. The first restrictions of the vehicle length to $24 \mathrm{~m}$ were introduced in 1969, whereas in 1996 they were increased up to $25.25 \mathrm{~m}$. At the same time the vehicle maximum authorized weight was increased from 37 up to 60 tons. The vehicles moved on the roads without any limits [2]. Since 2009, in the north of the country, regular transports of truck systems with the maximum authorized weight 90 tons and $30 \mathrm{~m}$ long were allowed. Such transport systems were used for transportation of wood [17, 18]. In 1988, in effect of an increasing number of transport services, a modernization program was introduced involving restructuring of road infrastructure to extend the maximum road capacities including bridges and viaducts. Such investments made it possible for $60 \mathrm{t}$ modular systems to move on all roads of the country. A long term research and EMS projects allowed to find out the impact of the European M odular Systems on the infrastructure, environment, health and safety. The studies indicate reduction in the car transport costs $[2,14]$.

A long term use of modular systems has not caused an increase in the number of accidents with involvement of this type of vehicles. Based on the carried out studies on operation and maintenance of oversized truck vehicles, it was found that despite a growth in road transportation by $30 \%$, the fuel consumption was reduced by $015 \%$. Implementation of this type of vehicle had no negative impact on the other transport branches. For the last years a railway modular transport has also been on the rise. Introduction of modular vehicles into the transport system has significantly reduced competition of railway with road transport which now complete each other in transport task accomplishment [2]. Current data indicates that Sweden is at the stage of tests of even longer and heavier vehicles. A fter introduction of new legal regulations, the maximum authorized weight for trucks will be up to 74 tons, and length up to $34 \mathrm{~m}$. It means that instead of one full dimensional trailer. such a vehicle will be able to pull two trailers which will have a positive impact on the natural environment. Currently, the maximum authorized vehicle weight in Sweden is 64 tones, whereas the maximum vehicle length 25.25 meters. As the above data shows, until recently the maximum gross vehicle weight was 60 tons, which indicates the dynamics of changes in this field. $[22,25]$.

\subsection{Netherlands}

The next European country to introduce $25.25 \mathrm{~m}$ long modular vehicles while increasing the maximum authorized weight was Netherlands. The first attempts were reported in1999, whereas, in 2001 successive actions were taken to introduce vehicles with the maximum authorized weight of 60 tons. I mplementation of such vehicles was divided into a few stages, in the first stage, in 2006, tests were conducted with participation of four transport companies. These tests lasted about 18 months and finished with positive results. The next stage was started in 2004, in which as many as 66 transport companies took part. The test results allowed to introduce 162 modular systems in 2006. The third stage of tests in 2007 involved determination of the impact of these systems on safety. A fter obtainment of positive test results, 397 transport companies started using the EM S on a regular basis. Implementation of modular transport systems in Netherlands contributed to reduction in the number of covered kilometers while increasing the load transported [2]. Based on the data collected from the tests, it was found that after implementation of oversized road vehicles, carbon dioxide emission reduction was reported from 63 to $56 \mathrm{~g} / \mathrm{tkm}$, which accounts for emission reduction of about $11 \%$ of $\mathrm{CO}_{2}$, and nitric oxide from 0.4 to $0.37 \mathrm{~g} /$ ton $\mathrm{NO} \mathrm{O}_{x}$, providing $14 \%$ reduction of $\mathrm{NO}_{x}[19]$.

Modular systems in Netherlands are used over long distances, mostly between harbors and distribution centers, whereas delivery and final distribution of goods of the transport 
chain is carried out with the use of smaller transport means. Such actions contributed to a significant increase in transport efficiency in Netherlands. [2]. N etherlands is at the stage of testing longer, $32 \mathrm{~m}$ long truck trains. Positive test results allow to enter these vehicles into service on a regular basis to be used for operation of distribution centers located near freeways [22].

\subsection{Denmark}

Due to its geographic location between Sweden and continental Europe, Denmark is an attractive country in terms of transport. Since 2008 Denmark has been conducting tests of the EM S to enter them into service [15]. Currently, the vehicle maximal authorized weight is 48 tons [26]. In 2009, 316 modular vehicles were registered in Denmark. They are used mainly for food and general cargo [2]. The end of the tests was scheduled for 2030. Extended time of modular vehicle utilization indicates that such transports are profitable. It al so makes it possible for transport companies to invest in longer vehicles to be used for transportation. Works on modernization of the existing infrastructure which involve extension of parking lots for 25 meter vehicles are being carried out in Denmark [15,22].

\subsection{Finland}

The next European country which implemented trucks exceeding the dimensions of 96/53/W E directive is Finland. In this country, like in Sweden, $25.25 \mathrm{~m}$ long vehicles with DCM 60 tons have been allowed since 1997. Finland is a country which has a well- developed industry, forestry and a long history of using oversize vehicles on the roads. B efore Finland entered the European U nion $22 \mathrm{~m}$ long articulated vehicles with the maximum gross vehicle weight 60 tons were allowed on the roads. Finnish registration slightly differs from Swedish legislation because in Finland it is possible to include a full $13.6 \mathrm{~m}$ long trailer in a $25.25 \mathrm{~m}$ long truck train, although it is not set out in the directive. This enables transport of heavier and larger cargo. Such a trailer is easier to maintain than a semi-truck, therefore, systems of vehicles with length $25.25 \mathrm{~m}$ are more popular in Finland than in Sweden. This kind of vehicles are not, however, allowed in international transport. [15].

Studies of real effects of modular vehicle implementation has been carried out in Finland. As analyses show, application of this type of vehicles also contributes to reduction in fuel consumption and V CO2 emission. In 2013 the Finnish government allowed to use vehicles with the maximum authorized weight 76 tons through introduction of legislative changes [27]. Since 21 J anuary 2019, 34.5 meter long vehicles are allowed to move on the roads in Finland. The Finnish ministry of transport expects that use of longer vehicles will provide benefits, especially in transport of sea containers, general cargo and food which account for $50 \%$ of all road transports in Finland. These vehicles were supposed to travel on routes between terminals, shopping centers and factories, mostly in night hours, beyond the rush hours [23].

\subsection{Germany}

Germany is the next country that has implemented the EM S system. In some regions tests of longer and heavier vehicle systems are being performed. Such solutions are being introduced into regular transport services in some lands [18]. Introduction of the EM S system has had a positive influence on the natural environment. Reduction in emission of $\mathrm{CO}_{2}$ and $\mathrm{NO}_{x}$ was $33 \%$. Based on the collected data, it is estimated that use of this type of vehicles increases energy efficiency of selected traffic routes [1]. On 1 J anuary 2017 trucks with the weight of 40 tons and length $25.25 \mathrm{~m}$ [25] were allowed to move on the roads. A ccording to initial calculations, it is estimated that an increase in the maximum gross vehicle weight to $44 \mathrm{t}$ (which is demanded by a large group of German companies) will allow to eliminate every seventh vehicle from the road. Currently, as the newest data shows, $25 \mathrm{~m}$ long trucks can travel to most of German cities and reach many borders including the Polish, A ustrian, 
Czech, Danish, French and Dutch borders. A ccording to the above data, utilization of this type of vehicles provides transport companies with many possibilities both on the territory of the country and abroad [22].

\subsection{Norway}

Norway is another Scandinavian country where laws concerning the vehicle maximum authorized weight and its length are being changed. Norwegian regulations, according to the Norwegian transport portal lanstebil.no regarding operation of vehicles, came into force on 15 J anuary 2020. As the new regulations provide, 24 long vehicles with one trailer/ semitrailer with the maximum authorized weight up to 60 tons are allowed to be used. So far trucks could be $19.5 \mathrm{~m}$ long and the maximum weight was 50 tons [22]. In N orway, 25 meter long trucks can move between locations without the necessity of having a permission. Norwegian ministry of transport wants to reduce transport negative effects for the natural environment and minimize transport costs [20].

\subsection{The remaining countries}

A part from the above mentioned countries, there are other countries which test transports with the use of $25.25 \mathrm{~m}$ long modular systems with the maximum authorized weight $60 \mathrm{t}$. One of these countries is Spain, where on 23 December 2015, new regulations that allow oversized vehicles to move on the road were introduced. It, however, requires special permissions from users of truck trains [22]. The Spanish government emphasized that use of such systems on the territory of Spain would increase efficiency, improve safety and competitiveness of those vehicles. [24]. The next country that is implementing the modular vehicles is Portugal. This country requires permissions from the transport companies. In 2019, two companies - X PO Logistics and Sociedad central de Cervejas e B ebidas were the first to take advantage of this option. U tilization of this type of vehicles is supposed to reduce transport costs and fuel consumption by $20 \%$ as compared to traditional transport systems. L ong vehicle systems were al so implemented in the Czech Republic. Permissions for use of $25.25 \mathrm{~m}$ long vehicles with the maximum authorized weight 48 ton, are issued by an authorized office and allow the vehicles to move only on freeways; They are issued to be used on a given route and for a period of three months with the possibility renewal [23]. One of the carriers that use such vehicles is Raben company (department in Czech). A I so B el gium uses the systems of modular vehicles, where since 2018 the maximum authorized weight 50 tons is entered into service 50 on the territory of south $\mathrm{V}$ alonia [22]

\section{Comparative analysis of European Modular System implementation}

$M$ any E uropean countries took the chance to departure from 96/53/W E Directive concerning the maximum dimensions of vehicles and their authorized weight. The purpose of the directive was to provide the countries with equal road transport conditions. The table shows data regarding countries which allow truck trains to move on the road.

Table 1. Countries which allow truck trains on the roads.

\begin{tabular}{|c|c|c|}
\hline EU & Vehicle length & $\begin{array}{c}\text { The maximum authorized } \\
\text { weight }\end{array}$ \\
\hline Sweden & $25.25 \mathrm{~m}$ & $64 \mathrm{t}$ \\
\hline Netherlands & $25.25 \mathrm{~m}$ & $60 \mathrm{t}$ \\
\hline Denmark & $25.25 \mathrm{~m}$ (tests to 2030$)$ & $48 \mathrm{t}$ \\
\hline Finland & $34.5 \mathrm{~m}$. & $76 \mathrm{t}$ \\
\hline
\end{tabular}




\begin{tabular}{|c|c|c|}
\hline Norway & $24 \mathrm{~m}(25.25 \mathrm{~m}$ on the basis of a permit) & $60 \mathrm{t}$ \\
\hline Germany & $25.25 \mathrm{~m}$ (some roads and some lands) & $40 \mathrm{t}$ \\
\hline Spain & $\begin{array}{c}18.75(25.25 \mathrm{~m} \text { on the basis of a } \\
\text { permission })\end{array}$ & $\begin{array}{l}44 \mathrm{t}(60 \mathrm{t} \text { on the basis of a } \\
\text { permit) }\end{array}$ \\
\hline Portugal & $\begin{array}{c}18.75(25.25 \mathrm{~m} \text { on the basis of a } \\
\text { permission })\end{array}$ & $\begin{array}{l}40 \mathrm{t} \text { (60 t on the basis of a } \\
\text { permit) }\end{array}$ \\
\hline Belgium & $\begin{array}{c}18.75(25.25 \mathrm{~m} \text { on the basis of a } \\
\text { permission })\end{array}$ & $\begin{array}{c}44 \mathrm{t}(50 \mathrm{t} \text { on the territory of } \\
\text { Valonia ) }\end{array}$ \\
\hline Czech & $\begin{array}{c}18.75(25.25 \mathrm{~m} \text { on the basis of a } \\
\text { permission })\end{array}$ & $48 \mathrm{t}$ \\
\hline
\end{tabular}

Based on an analysis of EMS implementation on the territory of particular countries, it can be said that there are countries which demand permission from vehicle operators to move on its territory, whereas in other countries modular systems are allowed to freely move on the road. Moreover, it can be observed that some countries have increased or are going to extend the maximum or/ and total authorized weight of the road transport vehicles.

In 2009, a study of extended modular vehicles was ordered by the European U nion. Based on the study result analysis, it was found that introduction of modular systems in the European Union on a wide scale would provide measurable benefits for particular state members. B ased on the carried out tests, many benefits of such a solution can be listed. One of the main benefits would be minimization of transport costs through increasing the carried loads as compared to traditional transport. The next positive factor would be a limit of internal and external costs due to reduction in the number of vehicles thanks to using modular systems as compared to the number of transports provided by single vehicles [2]. The next argument in favor of extension of vehicle systems is reduction in fuel consumption and $\mathrm{CO}_{2}$ emission. Truck manufacturers, associated in ACEA, call for extension of the modular vehicles up to $25.25 \mathrm{~m}$ or $32 \mathrm{~m}$ which would be an alternative solution for construction of ecological drive units. A s A CEA calculations show, in the $25.25 \mathrm{~m}$ variant, the emission of carbon dioxide would decrease by $15 \%$, whereas, fuel consumption by $14 \%$. For the variant of $32 \mathrm{~m}$, these figures would be: $27 \%$ for $\mathrm{CO}_{2}$ emission reduction, $29 \%$ for fuel consumption. ACEA calculation for trucks with different dimensions [25].

The next factor confirming purposefulness of modular system introduction is a demand for transport. A ccording to data from 10 years, a demand for freight transport in the E uropean Union will significantly increase. Implementation of high capacity modular systems in particular countries could be one of the solutions to enable transport of a larger amount of goods as compared to standard vehicle systems [16].

\section{Conclusions}

Based on an analysis performed for the European Modular Systems, it can be said that introduction of modular systems into European countries is justified. The analyzed countries tend to implement new solutions which would increase load capacity of vehicles limiting the amount of exhaust gases emitted to the natural environment. Such actions provide benefits both for a given country and for the whole Europe. As the presented analyses shows, use of the EM S systems will allow to provide efficient functioning of transport companies and meet the customers' demands, increase in the efficiency of provided services and savings connected with reduction in costs and in the number of covered kilometers while increasing the number of transport services which will improve road transport efficiency and boost the development of intermodal transport. It will decrease road congestion through providing 
higher load capacity for fewer transports and will reduce freight transport emissivity, hence contributing to climate change reduction. Based on the analyzed data it can be said that extending the vehicle length and mass and application of the European modular system can provide benefits for both transport companies and the entire economy. The analysis shows that implementation of transport modular systems is taking place in many European countries. In some countries such vehicles are operated all over the country with no limits, whereas in others it is possible only in some regions ad they can use only freeways and highways between the scheduled places. In other countries a special permission is to be issued by an authorized institution. Data obtained from literature analysis, indicates that application of EM S systems makes it possible to limit exhaust gas emission into the natural environment through increasing load capacity one of the system vehicle. Appropriately arranged and distributed load in a trailer/semitrailer will not adversely affect the state of road infrastructure as the pressure exerted on each axle of the vehicle does not change. B enefits provided by use of such systems encourage their wider application and new legal law implementations.

\section{References}

1. A. Dzioba, S. Kilimnik, Ł. Muślewski, M. Markiewicz, Infrastrukturalne uwarunkowania wdrożenia zestawów modułowych EMS w samochodowym transporcie drogowym - Czasopismo naukowo-techniczne, „Postępy w inżynierii mechanicznej” Wydawnictwo Uczelniane Uniwersytetu Technologiczno-Przyrodniczego w Bydgoszczy, No 14 (2019)

2. J. Poliński, Konkurencja pociągów drogowych dla transportu kolejowego w Europie, Przegląd Komunikacyjny, No 5 (2014)

3. B. Wiśnicki, W. Galor, Uwarunkowania przewozu ładunków pojazdami niestandardowymi w Europie, Logistyka, No 2 (2010)

4. Markiewicz M. Muślewski Ł., Pająk M., Impact Of Biocomponent Additive To Diesel Oil On V alues Of Elected Functional Parameters Of Transport M eans, Polish J ournal Of Environmental Studies, V ol. 29 (2020).

5. Markiewicz M., Muślewski Ł., Survey performance and emission parameters of diesel engine powered by diesel oil and fatty acid methyl esters using fuzzy logic techniques, Fuel, V ol. 277 (2020).

6. Markiewicz M., Muślewski Ł., The Impact Of Powering An Engine With Fuels From Renewable Energy Sources Including Its Software Modification On A Drive Unit Performance Parameters, Sustainability, V ol. 11 (2019).

7. B. Landowski, M. Baran, Analysis of selected results of engine oil tests, 18th International Conference Diagnostics of M achines and V ehicles (2019),

8. B. Landowski, M. Baran, Analysis of changes in the value of selected lubricant characteristics during use, 18th International Conference Diagnostics of M achines and $\checkmark$ ehicles (2019)

9. Ń. Lińčák , K. Olejnik, G. Woźniak, Propozycje i ocena możliwości zwiększenia rzeczywistej pracy przewozowej środków transportu drogowego, Motor Transport Institute, W arszawa (2012)

10. Pająk M., Muślewski Ł., Landowski B., Grządziela A.: Fuzzy identification of the reliability state of the mine detecting ship propulsion system. Polish M aritime Research, No 26 (2019).

11. Kostek R., Landowski B., Muślewski Ł. Simulation of rolling Bering vibration in diagnostics. J ournal of V ibroengineering, I ssue 8 (2015).

12. Landowski B., Pająk M., Żółtowski B., Muślewski Ł.: Method of building a model of operational changes for the marine combustion engine describing the impact of the damages of this engine on the characteristics of its operation process. Polish M aritime Research, vol. 24 (2017). 
13. B. Landowski, Ł. Muślewski, Decision model of an operation and maintenance process of city buses, Proceedings of 58th International Conference of Machine Design Departments - ICM D 2017, Publisher: Czech University of Life Sciences Prague, Czech Republic (2017)

14. K. Lumsden, Truck Masses and Dimensions - Impact on Transport Efficiency, Department of Logistics and Transportation, Chalmers University of Tehchnology, Gothenburg (2004)

15. I. A kerman, R. Jonsson, European Modular System for road freight transport experiences and possibilities, Sztokholm (2007)

16. http://www.modularsystem.eu

17. D. Milewski, B. Wiśnicki, Wpływ kosztów eksploatacji wielkogabarytowych zestawów drogowych na rynek transportowy w Polsce, Zeszyty Naukowe Uniwersytetu Szczecińskiego. Problemy Transportu i Logistyki, No 26 (2014)

18. Ł. Muślewski, M. Lewalski, M. Woropay, Analysis and evaluation of application of car modular systems in polish road transport, J ournal of K ones, No 22 (2015)

19. Ł. Muślewski, B. Landowski, M. Woropay, K. M igawa, Implementation of Modular Trucks into Road Transport, Journal of K ONBiN, No 44 (2017)

20. A. W ojcieszak, Europejska koncepcja mega-ciężarówek, Log24, No 3 (2013)

21. L. Cider. L. Larsson, HCT DU 02-project Gothenburg-Malmö in Sweden (2019)

22. https://40ton.net/

23. https://blogtransportowy.pl/

24. https://www.cadenadesuministro.es

25. https://spidersweb.pl

26. http://www.strychalski.eu

27. H. Liimatainen, M.Pöllänen, L. Nykänen, Impacts of increasing maximum truck weight - case Finland, E uropean Transport Research Review, volume 12, No 14 (2020) 